\title{
Study on Wedding Customs in Uygur Folk Dastan*
}

\author{
Rousitaimujiang Abudouriyimu \\ School of Uyghur Language and Culture \\ Northwest Minzu University \\ Lanzhou, China730030
}

\author{
Aili Tuxunayi \\ School of Uyghur Language and Culture \\ Northwest Minzu University \\ Lanzhou, China730030
}

\begin{abstract}
As a crucial part of the people's spiritual life, folk Dastan is one of important ways for people to exchange information, communicate ideas, express emotions and ideals, and preserve culture. Throughout a lasting process of human production and living activities, Dastan has become a part of Uygur life, fulfilling the spiritual needs of the people and revealing the details of their lives. This paper mainly analyzes the relevant wedding customs in Uygur folk Dastan to illustrate that the infiltration of Uyghur national traditional culture in Dastan is a collective unconscious manifestation of an art form created by Dastan.
\end{abstract}

Keywords-Uygur folk Dastan; Uyghur wedding ceremonies; customs

\section{INTRODUCTION}

As an art form created by the people themselves, Dastan represents the splendid folk culture of Uygur, with Uygur marriages and funerals, folk Masirif and religious activities in particular. The following is personal views and understanding on Uyghur's historical Dastan wedding folk culture.

Marriage is the most basic system and activity for the continuity of mankind and society. From the perspective of the overall human development, the constant evolution of the marriage system has formed unique and traditional marriage customs in various ethnic groups. Marriage, as a symbol of social civilization, carries abundant folk custom elements. The Uyghur wedding has its own traditional customs. It has become a regular custom with a universally applicable set of patterns composed of a series of stages. These components are determined in quantity, and the absence and impairment of any factor do not conform to the concept of the group; they are fixed in the arrangement as well, and no one in the group is willing to change its collocation. There are some differences in Uyghur wedding ceremony customs in Xinjiang though; these customs have something in common. For example, customs such as "proposing a marriage", "sending betrothal gifts", "escorting the bride to the wedding ceremony", and "ceremonies" are essential to Uighur weddings. Let's take a look at these customs in Uygur folk

*This paper is a phased achievement of the Northwest Minzu University for postgraduate innovation project "Uygur Folk Love Dastan Research from the Perspective of the One Belt and Road

Initiative"(Yxm2017004 ) and National Social Science Fund "Uygur Folk oral poetics for the research"(15BZW196).

Doctoral student project of northwest minority literature research center "Study on the form of stories of uyghur folk dastan" (2018004B)
Dastan:

\section{A. Proposing a Marriage}

Wu Bing'an, a famous Chinese folklorist, referred in his book Chinese Folklore: "The birth of the matchmaker has a long history in China. Marriage gradually transited to autocracy when patriarchy and private ownership came into being, and matchmaker is the product of marriage negotiation ${ }^{1}$.

Marriage proposal means that man' $s$ family asks a matchmaker on behalf of their son to discuss the marriage with woman's family. Arranging a matchmaker has been a traditional custom with long history in Uygur. In a Uygur marriage, a matchmaker not only proposes the marriage, discusses betrothal gifts, but also deals with various details of the wedding ${ }^{2}$. In Eleventh Century, Mahamud Kashgar, a famous Uygur scholar, recorded some words in the Turkish Dictionary: "sowchi", "yorighuchi”, "yazighchi”, "arquchi”. He said: "sowchi" refers to the person who communicates between the two parties of a marriage; "yorighuchi" to people who are connected with their in-laws; "yazighchi" to the person who delivers letters between relatives; and "arquchi" to the medium between relatives during the wedding. Since ancient times, "matchmaker" has enjoyed a high social status, as the Uighur folk proverb "elchige olum yoq" (the matchmaker is innocent) says.

In folk Dastan Mayi Mu Khan, the process of marriage proposal between Mayi Mu Khan and Yiti Buck is described as follows: The men and women, matchmakers of Yiti Buck come to Mayi Mu Khan's home and say: "Hello, my good people, we miss your hospitality so much that we come to see you. To bring a good man to your beautiful hometown and to your warm house we come to see you. This is Salat alSunnah that our ancestors left behind." Hearing this, Mayi $\mathrm{Mu}$ Khan's parents stand up and reply "Thank you!" three times, which means they agree to the marriage.

Another example. In Prince Kmel and Princess Shemsey, Prince Kmel asks Uncle Sally Maas to go to the imperial palace to propose a marriage. Sally Maas says:"Boy, it's too dangerous to do so because the king will not accept poor people like us. He will kill me if I tell him what you want."

Anbing Wu,Chinese Folklore,Liaoning university Publishing House, 1999, First edition: 38

Risat Ganj,A Turkic Dictionary Looks at the Social Status of the Karahan Dynasty,the Ethnic Publishing House,2010, First edition: 102 
"The matchmaker is innocent," Prince Kmel says, "Please, I'm willing to die for you if the king wants to kill you." "Ok. Sooner or later, I will die. I agree to help you before this day comes." Uncle Sally Maas promises. Then he goes to the palace with his violin and sings a song before King XiaPa Kuti:

\section{Your Majesty, the leader of the people,}

You are my most respected person, the greatest master.

I come here, your sacred palace, for a reason.

I am totally true to you. Please listen to me

The desire is harmless and the matchmaker is innocent.

Forgive me, you will be happy.

A handsome man expresses his love for Princess Shemsey,

If you reject him, he will die.

This lyric depicts how matchmaker propose a marriage to the King on behalf of Prince Kmel, illustrating that this kind of ceremony has existed in the early Uygur and gradually evolved into the form of saying instead of singing. Perhaps it is possible to have Dastan been a matchmaker in the past.

\section{B. Sending Betrothal Gifts}

Sending betrothal gifts has been a marriage custom of Uyghur people for millennia. According to this custom, man' s family should send betrothal gifts when they visit the lady' s home. There is a saying that betrothal gifts represent a kind of respect for the woman and the gratitude to her parents for raising the daughter ${ }^{3}$.

In folk Dastan Mayi Mu Khan, they return to get the list of betrothal gifts prepared by Mayi Mu Khan's parents three days after the matchmaker proposing the marriage. Yiti Buck's father is satisfied, and then he comes to Mayi Mu Khan's home to thank them and returns. After that the engagement ceremony is held, followed by a wedding ceremony.

In Prince Kmel and Princess Shemsey, King XiaPa Kuti cannot stand to listen to his proposal, therefore he calls butcher in, with 18 butchers coming at once. The King orders "Kill this ignorant old fart immediately!" Then butchers bring him to the execution ground. King XiaPa Kuti has a brilliant hero who comes across Uncle Sally Maas on his way to the execution yard. The hero asks what crime he has committed. The butchers answer that he is a matchmaker. "Don't kill him before I come back" the hero says. Then he goes to meet the King and says "Your Majesty, it's good to have someone propose to your daughter. As the saying goes "The matchmaker is innocent." You can't kill him. Those who kill innocent people will be punished." The King reluctantly consents to the hero. "Another saying goes 'Unwilling to get the daughter married, the bride price must be heavy.' If you don't want the princess to marry him, we

Aibibula Abudoureyimu,Customs and Records of Uyghur Nationality,Xinjiang People's Publishing House, 1993, First edition: 244 can ask him to send a betrothal gift that cannot be prepared. Then he will give up." Uncle Sally Maas is exempted from death penalty. He returns home and brings news to Prince Kmel who is looking forward to the reply day and night. King XiaPa Kuti asks him to build a four-season garden in the Gobi Desert as a betrothal gift for princess. Prince Kmel faints on hearing this. This kind of betrothal gift is indeed different from the modern, from which we can identify Uygur's aspiration for Oasis Garden similar to the paradise garden in its mythology. The description of heaven and garden in Uygur mythology is the same, so creating a garden in the past is tantamount to a living garden. This gift in Dastan is not money, nor food, nor animals but the environment people can live in, which is a manifestation of Uygur people's longing for green in the desert. Such consciousness still exists in Uyghur's life until now.

\section{Escorting the Bride and the Wedding Ceremony}

The Uighur wedding ceremonies are grand and full of joy, usually lasting two or three days. On the first day, the bridegroom and the bride will give a banquet at their respective homes. People play the dutars, rawaps and drums, singing and dancing. The courtyard is filled with joy and laughter. Dressed in beautiful clothes, the bride accompanied by the bridesmaid and friends who come to offer their congratulations, gather at her neighbor's home. She sits on the rug of the kang, and the girls sing and dance in the limited space inside the house, waiting for the groom's procession. While the groom plays the instruments, sings and dances with his friends and the best man who come to celebrate in the courtyard of his home, aspiring to the advent of escorting the bride. At the night before or on the morning of the wedding, the bride is gussy up in the wedding gown and waits for the groom with a veil.

The bridegroom surrounded by relatives and guests goes to bride's home to pick up the bride. The lads sing "welcome the bride" in cheerful mood, playing the drum, suona and rawap along the way. As soon as the relatives and friends of the bride hear the arrival, they shut the door and ask for gifts to let the procession in. The bride's family will entertain the guests. Everyone dances in the courtyard of the bride's house. Before the guests leave, the bride will bid farewell to her parents and ask them to bless her marriage. The bride's father blesses and prays for her daughter in front of everyone, while the bride can't help shedding tears wistfully. Then the lads sing "Persuasion." On the way back, the men of procession walk ahead playing instruments and singing songs followed by the bride and bridegroom on the float with the women of procession at the very end of the line ${ }^{4}$.

"Escorting the bride" in Dastan represents with a 40-day grand wedding. In Sin Bayer, Sin Bayer, the only son of the King of Qin Ninimaqin, has a dream about a fairy. He leaves to find his lover regardless of relative's dissuasion. Finally, he finds and brings her back home and has a 40-day ceremony after experiencing a lot of difficulties. In Prince Kmel and Princess Shemsey, King XiaPa Kuti is surprised

\footnotetext{
Abilikemu Guohaiernisa,From the Uyghur History to See the
} Folk Culture Phenomenon,Journal of Kashi University, 2015.3: 40 
when he sees the garden Kmel builds in the desert. But he goes back on his promise of having his daughter married. Soon afterwards the King gets seriously ill being unable to see or talk. The queen orders that the person who cures the king's disease can succeed to the throne. Prince Kmel asks to marry his daughter after he has cured the King's illness. The King finally agrees to the marriage and holds a grand wedding for them. Later, Prince Kmel returns to his country with his wife.

\section{The MEANING AND FUnCTION OF THE WEDDING CUSTOMS IN DASTAN}

It enjoys high historical literature value and research significance for preserving the traditional form and historical evolution of Uygur marriage customs. Although there are differences in the composition and expression of marriage customs in different Dastan, its basic form and cultural meaning are similar to the contemporary Uyghur marriage customs, which proves that there is a certain inheritance relationship between them. These marriage customs appear in different Dastan's works and perform in different periods and places, which is in line with the consensus that a folk custom consolidates itself, sets up authority and strives for legal status in a certain culture through constant repetition. Therefore, the marriage customs in Uygur Dastan also play the role in inheriting and regulating Uyghur traditional marriage customs.

As the most important part of life etiquette, the marriage customs have enriched the connotation and form of the folk Dastan, and played a key role in portraying the personality of Dastan, expressing the creative gist, and constructing the plot. They make Dastan closer to the daily life and culture of the people, help people to accept and understand Dastan more easily, and are also conducive to the wider spread and inheritance of folk literature.

The marriage customs in Dastan serve as a turning point in stylized fixed footages and narratives in the process of creation and singing, bringing convenience to performers and making Dastan easier to remember. Moreover, the wedding in Dastan is often a big turning point in the whole narrative. For example, at the beginning of Ariff and Senam, the King and the chancellor betroth their children when their wives have the delivery, which is the foundation and contradiction of the whole story. The main characters in Dastan are fighting around this engagement. The King wants to break of the engagement which the couple, Ariff and Senam, swears to fulfill. Besides, cultural awareness of the mysterious digital beliefs among the Uighur people represents through the three-day wedding or the seven-day wedding or the 40-day wedding mentioned in Dastan. Therefore, the flexible use of this component by performers can better attract the audiences' attention and recognition.

\section{CONCLUSION}

In summary, we discussed the wedding customs culture in the Uighur Dastan history. As the crystallization of the collective creation of the people, the folk Dastan expresses their splendid cultural life. In other words, every detail of
Dastan infiltrates the traditional culture of the nation. We just selected typical wedding customs to explore. Because it is expressed for a certain purpose of creation in the historical Dastan and plays an important role in achieving the purpose of creation. The infiltration of Uyghur national traditional culture in Dastan is a collective unconscious manifestation of its creators in such an art form.

\section{REFERENCES}

[1] Aladukelimu-Reheman.(1989,July).The Introduction to Uygur Folklore. Xinjiang University Press

[2] Wu Bing'an(1999,September).Chinese Folklore. Liaoning University Press

[3] Abuduwaili-Keremu(2014,June). Uygur Folk Dastan. Guangming Daily Press

[4] Rexiade-Ganji(2012,November). The Social Situation of the Kala Khan Dynasty in the Turkish Dictionary. Nationalities Publishing House

[5] Abuduwaili-Keremu(2014,June). Research on Uygur Folk Oral Dastan. China Social Sciences Press

[6] Abudureyimu-Aibilabu(1993,April). Uygur Customs Records. Xinjiang People's Publishing House 